\title{
.
} DE GRUYTER OPEN

\section{IDENTIFYING POLLUTANTS IN THE SIRET RIVER BASIN BY APPLYING NEW ASSESSMENT TOOLS ON MONITORING DATA: THE CORRELATION OF LAND USE AND PHYSICO- CHEMICAL PARAMETER OF WATER QUALITY ANALYSIS}

\author{
Andreea Mănescu ${ }^{1}$, Luca Mihail, Mihalache Raluca \\ Key words: Sources of pollution, water quality monitoring, GIS, land, use,
} catchment.

\begin{abstract}
The Siret River are used as raw water source for different municipal water supply systems, yet the Siret River are used as receiving bodies by some inhabitants and industry. In the study the quality of the Siret River water was determinate using a Water Quality Index (WQI). Results are presented from a field study performed on the Bistrita, Moldova, Suceava, Siret, Şomuzu Mare, Trotuş and Tributary River in the study area Siret Basin Romania. The main objective of this study was to determine is to find correlations land use to indicators physical-chemical of water quality, to investigate pollution source is more responsible for river water quality. This is of interest not only research context, but also for supporting and facilitating the application analysis postullend in the Water Framework Directive (WFD) (2000/60/CE) for the establishment of programmers of measures. For this purpose a slightly impact pollution source municipal wastewater treatment, land uses, urban, forest, agriculture and mining was selected and intensively monitored during six years January 2006 - December 2011, sampling was determined to meet the WFD standards for confidence in twenty two different control section of the Siret Basin. The main measures to reduce emissions to the Siret River were calcium, ammonium, sulfate, residue fixed (RF), sodium, chloride, free detergent and municipal wastewater treatment, concentrated on point emission. The main contributor to diffuse this parameters increased when more percentage of land was dedicated to industry and urban and less to forest and mining.
\end{abstract}

\footnotetext{
${ }^{1}$ manescuandreea_85@yahoo.com
} 


\section{Introduction}

This study identifies data and information requirements, pinpoints difficulties the impact of pollution source, analysis of water quality and monitoring control. The main measures to reduce emissions to the Siret River were calcium, ammonium, hydrogen sulfide, residue fixed (RF), sodium, choride, free detergent and municipal wastewater treatment, concentrated on point emissions. (Behrendt and Bachor, 1998; Laane et. al., 2002). The aim of this analysis is to find a correlation between land uses, industry, urban, forest, mining and agriculture, for the defined diffuse source of the variation indicators physical-chemical and to deliver strategic guidelines for water protection. The EU Water Framework Directive (WFD) prescribes to achieve a good status of surface waters by 2015 (European Parliament, 2000). To keep this deadline of a new three level surveillance, operational and investigative, monitoring systems is required including hydro-morphological, biological and chemical elements. (Balazs L., et. al., 2006). In consequence, the physical-chemical status of European river should be evaluated and investigated before the year 2015 for a good improved.

This is a strategy for assessing the physical-chemical status of Siret River by using multiple indicators by observed deviation from the expected natural condition. The methodological focus used in this study offers a more global, complete view, as seen in other paper where the use of multiple parameters of analysis of water quality (Roth et. al., 1996, Lammaert and Allan, 1999, Griffth et. al., 2005, Freund and Petty, 2007). In the process of pollution, rivers in a watershed play a major role in assimilating or carrying off municipal and industrial wastewater and runoff from agricultural land (Alexander et al., 2000; Singh et al., 2005). Thus, it is imperative to prevent and control river pollution. Spatial and temporal variations in water chemistry and the locations of the most significant contributors to pollution in a river basin must be clearly identified; this usually requires a monitoring program that will provide a representative and reliable estimation of the quality of surface waters (Alexander et al., 2000; Simeonov et al., 2003). Identification of the point source and non-point source pollution in a watershed with complex river network is an environmental conundrum. Different multivariate approaches offer powerful means of understanding a large environmental datasets and the physical-chemical status of study systems (Simeonov et al., 2003; Singh et al., 2005; Zhou et al., 2007).

The control of diffuse pollution is very important in this paper there for we analyze the effect of some land uses agriculture, urban, forest, mining, industry, responsible for different impact source of water quality. Where agriculture cause point pollution, the level of irrigation impact it is not responsible for high values of the parameter analyzed. Urban often causes is the most important source of diffuse pollution point in the Siret basin. The wastewater discharged is the source 
responsible of water quality. Some autors have suggested that the influence of the land uses on water quality must be analysed at the catchment scale (Omernik et. al., 1981; Richards and Host, 1994; Roth et. al., 1996), where others have argued that land uses located closer to stream are more important. (Harding et. al., 1998; Nerbonne and Vondracek, 2001). Many studies suggest a multiple spatial scale approach could be a framework and important source of diffuse pollution. (e.g. Chamg, 2008; Tran et. al., 2010). The effect of urban in TSS, $\mathrm{NH}_{4}, \mathrm{RF}, \mathrm{Cl}, \mathrm{SO}_{4}$, $\mathrm{Na}, \mathrm{Ca}$ river concentration was also in the Siret basin.

\section{Material and methods}

1.1. Study area. The indices of water quality have to be developed considering the local properties and pollution status of the ecosystems. There are different tools that affect watershed management and to control.

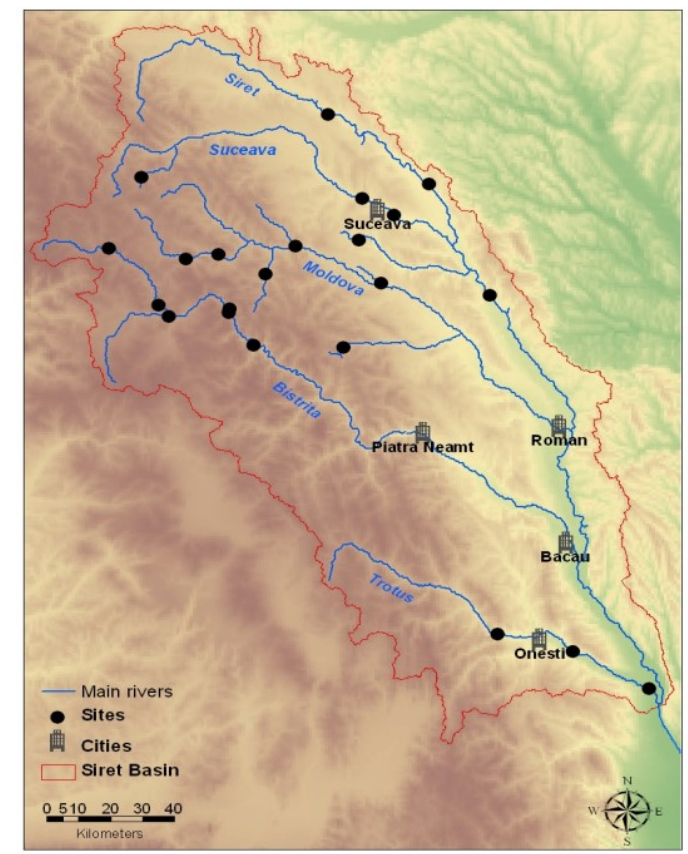

Fig.1. Study area Siret River Basin and the boundaries of river

Water Quality Index is a very important tool in the management of watersheds in this sense. Therefore this study has the potential to provide interesting results for researchers in water quality sector. The study area is Siret River Basin, Administration (ABAS), Romania area that includes the upper and middle reaches 
of six large river Bistrita, Moldova, Suceava, Siret, Şomuzu Mare, Trotus and Tributary River (Fig.1). The Siret River Basin, which is the largest basin in Romania, with a 47,610 square kilometers area of which $42890 \mathrm{~km}$ on Romanian territory. In this basin area, Siret River Basin Administration Bacău manages $27,402 \mathrm{~km}$. The density of the river network is $0.35 \mathrm{~km} / \mathrm{sq}$. km. Siret River, rises in the Carpathian Woody Mountains, in Ukraine enters in Romania near the city of Siret and flows into the Danube, upstream the Galati city. The total length of the Siret River is $726 \mathrm{~km}$, of which the territory of Romania, $559 \mathrm{~km}$. The main tributaries of the Siret River are Suceava River, Moldova River, Bistrita River, Trotuş River, Bârlad River, Putna River, Ramnicu Sarat River and Buzau River, which together with other smaller tributaries, contribute to a multi-annual average flow of Siret River upstream the confluence with the Danube, approximately 240 $\mathrm{m}^{3} / \mathrm{s}$ corresponding to a multi-annual average stock of about 7.6 billion cubic meters. The total length of the river system of the Siret River Basin, is $15836 \mathrm{~km}$, of which on the territory of Romania, $15157 \mathrm{~km}$, and managed by Siret River Basin Administration of $10280 \mathrm{~km}$.

Main water courses from the Siret river basin are effluents of Siret river that collects all the waters on the eastern side of the Carpathians rivers namely Suceava, Moldova, Bistriţa, Trotuş, Putna and Ramnicu Sărat, Buzău River. In the surface water resources of the Siret River Basin there are two lakes, one freshwater and one saltwater, their water not being used to meet requirements of water using.

Areas occupied by forests and bushes are there (58.29\%), are being developed and expanded on surfaces in compact, high relief areas (Fig.2). Perennial crops and heterogeneous agricultural areas $(12.17 \%)$ have a relatively uniform development throughout the surface of the water. Arable land represents lie on the east side of the basin of hilly area and along the embankment of the Siret River in percentage $(22.7 \%)$. Other occupies the area significantly lower. Thus, the water occupies a large proportion of $0.59 \%$ and wetlands occupy a large proportion of $0.08 \%$ (Fig.2). The Siret River basin in the area is the predominant type of calcareous rocks, limestone with a North-South alignment, with relatively small areas along the Carpathian Arc, crystalline-mesozoic area. In the northern part of the West are small areas of organic material. Underground water resources and deep groundwater are located in most major rivers Siret, Suceava, Moldova and Bistriţa, groundwater is estimated at $28 \mathrm{mc} / \mathrm{s}$ whereby $16,7 \mathrm{mc} / \mathrm{s}$ are balance resources. Unlike other rivers, Siret River has several major tributaries, which are expressed more strongly by the variation of annual average flow along its course (Suceava $9 \%$, Molodva $17.6 \%$, Bistriţa 35\%, Trotuş $18 \%$ ). Water pollution is reduced substantially from its initial value due to its self-purification capacity. Treated or untreated wastewater, after evacuation processes are subjected to physical, chemical and biological processes that lead - finally - to water self-purification of 
the receptor.

\subsection{Land use data}

The development of geographical information system (GIS) tools has allowed more sophisticated questions to be asked about how community composition in a stream is related to its physical setting at a variety of scales (McDonnell,2000). In this context, attention has often been focused on whether conditions in the catchment have been strongly modified by human influence, agriculture, forestry, mining, industry, or are largely natural (Basnyat et.al., 2000; Manel et.al., 2000; Prosser et.al. 2001). Some researchers have used exploratory data analyses to elucidate relationships in their data (e.g. Carter et. al., 1996; Allen et.al., 1999; Li et.al., 2001; Monaghan et.al., 2000) while others have built predictive models (e.g. Manek et.al., 2000), which may be of direct use for management purposes. All geographic data management was carried out whit Arc GIS 9.2. Land use percentage composition for each site was quantified with four different spatial scales. Total upstream drainage are for each location was delineated based on data and images form the USGS HydroSHEDS and BioFresh dataportalBiodiversityofFreshwaterEcosystems, http://data.freshwaterbiodiversity.e $\mathrm{u} /$ shapefiles.htmland http://hydrosheds.cr.usgs.gov.

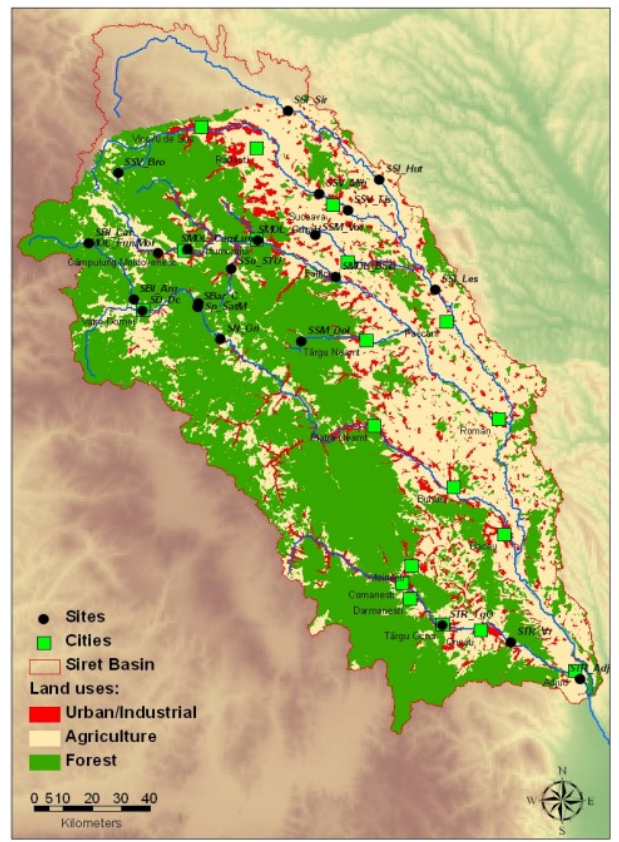

Fig.2. Study area Siret River Basin the boundaries of river and land use 
In this paper, we analyze data base of 22 sites in the Siret River Basine using a newly developed GIS.

The objectives were to determine which scale of landscape variables accounts for most variation of parameter physical chemical, geographical position, catchment, whether natural or human induced physical setting, impact pollution.

Tab. - 1 Description of land uses analyzed Corine Land Cover categories

\begin{tabular}{|c|c|c|}
\hline Code & Description & $\begin{array}{c}\text { Corine Land Cover } \\
\text { categories }\end{array}$ \\
\hline Urban & $\begin{array}{c}\text { Urban } \\
\text { Industrial } \\
\text { Wastewater discharged }\end{array}$ & 1. Artificial areas \\
\hline Mining & $\begin{array}{c}\text { Extractive mining industry } \\
\text { Construction sites } \\
\text { Mining water } \\
\text { Dump sites }\end{array}$ & 2. Artificial areas \\
\hline Agriculture & Cereals, legumes, fruits trees & $\begin{array}{l}\text { 3. Non-irrigated } \\
\text { arable land } \\
\text { Agricultural areas }\end{array}$ \\
\hline Forest & Areas with natural vegetation & $\begin{array}{l}\text { 4. Forest and semi-natural } \\
\text { vegetations areas }\end{array}$ \\
\hline Water & $\begin{array}{l}\text { Water courses } \\
\text { Salinas }\end{array}$ & 5. Water bodies \\
\hline
\end{tabular}

Was obtained by Geographical Information System (GIS) software (ESRI ArcMap 8.2). The GIS has been using the more recent database from regional and national sources. The category land uses data is: urban, forest, mining and agriculture. Land use data were obtained from the Corine Land Cover (CLC, 2000). Land cover classes characterized in CLC were reclassified intro the following category (Table 1). Areas to agricultural (AGR), urban and industrial land covers (URB), natural and forested vegetation (FOR), mining and extractive mining (MIN) and water (WAT). Urban land use was also split intro three categories: industrial, wastewater discharged and urban, expected to have o low impact on quality water of Siret River.

\subsection{Physical - chemical analyses}

Water pollution is reduced substantially from its initial value due to it's selfpurification capacity. Treated or untreated wastewater, after evacuation processes are subjected to physical, chemical and biological processes that lead - finally - to 
water self-purification of the receptor. The main source of pollution of the Siret River is due mainly to disposal of wastewater and usually directed by inappropriate treatment. Pollution of the Siret River, the urban sewage treatment station downstream of city, due to sewage discharged and improperly purified by the purge station. In this situation the water quality is influenced by the presence of $\mathrm{Ca}$, $\mathrm{N}-\mathrm{NH}_{4}, \mathrm{RF}, \mathrm{Na}$. This fact demonstrates the strong influence of urban in stream water $\mathrm{Ca}, \mathrm{N}-\mathrm{NH}_{4}, \mathrm{RF}, \mathrm{Na}$ level within the study area.

The main sources of pollution in the catchment area have influenced the state of its river water quality. The highest pollution input was recorded in the Siret Basin coming the tow tributaries (Suceava, Bistrita, Moldova, Şomuzu Mare, Trotuş) due at least partly to the collection of urban wastes from the metropolitan of Suceava, Bacau. Mean values of $\mathrm{Ca}, \mathrm{N}-\mathrm{NH}_{4}, \mathrm{RF}, \mathrm{Na}$ due to extensive urban use and accidental pollution (Table 4).

\subsection{Statistical analyses}

Statistical analyses were performed using STATISTICA StatSoft v.10 and XLSTAT. Statistical software was used for all statistical treatments such as basic statistic, analysis of variance and correlations. In this case we calculate Sperman's rank correlation coefficient for each scale dataset. Basic statistical analysis has been conducted in order to gain some insight into the structure of the dataset.

Tab. - 2 Description total drainage area of upstream sub catchment (DA)

\begin{tabular}{cccccc}
\hline Section Siret River basin & Urban \% & Mines \% & Agriculture \% & Forest \% & Water \% \\
\hline SBar_C & 0.12 & 0.00 & 16.78 & 83.10 & 0.00 \\
SBI_Arg & 6.97 & 0.00 & 80.74 & 12.29 & 0.00 \\
SBI_Car & 27.14 & 0.00 & 56.36 & 16.50 & 0.00 \\
SD_Dc & 78.42 & 0.00 & 3.72 & 17.86 & 0.00 \\
SMOL_Baia & 40.18 & 0.00 & 59.82 & 0.00 & 0.00 \\
SMOL_CamLung & 75.34 & 0.00 & 5.1 & 19.56 & 0.00 \\
SMOL_Fun Mol & 32.64 & 0.00 & 37.88 & 29.48 & 0.00 \\
SMOL_GuraHum & 57.87 & 0.00 & 0.00 & 35.79 & 6.34 \\
SN_Gn & 30.75 & 0.00 & 35.84 & 24.14 & 9.27 \\
SP_SatM & 13.63 & 0.00 & 52.04 & 28.19 & 6.14 \\
SSI_Hut & 0.00 & 0.00 & 100.00 & 0.00 & 0.00 \\
SSI_Les & 41.11 & 0.00 & 40.42 & 0.00 & 18.47 \\
SSI_Sir & 26.64 & 0.00 & 63.74 & 0.00 & 9.62 \\
SSM_Dol & 23.55 & 0.00 & 0.00 & 76.45 & 0.00 \\
SSM_Vor & 4.17 & 0.00 & 95.83 & 0.00 & 0.00 \\
SSU_Stu & 44.04 & 0.00 & 38.74 & 7.23 & 9.99 \\
SSV_Bro & 0.00 & 0.00 & 49.99 & 50.01 & 0.00 \\
SSV_Mih & 5.80 & 0.00 & 79.84 & 0.00 & 14.36 \\
SSV_Tis & 50.52 & 0.00 & 22.66 & 0.00 & 26.82 \\
STR_Adj & 0.00 & 0.00 & 55.62 & 0.00 & 44.38 \\
STR_TgO & 71.48 & 0.00 & 21.70 & 0.03 & 6.79 \\
STR_Vr & 9.49 & 0.00 & 75.82 & 4.98 & 9.71 \\
\hline & & & & & \\
\hline
\end{tabular}


For the estimation of statistical properties of the data, the missing values have been temporarily ignored and the dataset has been scaled.

According to the characteristics of their special distribution, the pollution sources are classified as point sources, non-point sources and internal sources discharged into rivers and lakes. Point pollution sources mainly include industrial and domestic wastewater from urban areas. Non-point pollution sources comprise of the pollutants from surface runoff from agriculture lands, town lands, woodlands, meadows and so on (Wang C. et.al., 2005).

The pollution loads of urban point source are non-point sources. It indicates that the amount of $\mathrm{Ca}, \mathrm{N}-\mathrm{NH}_{4}, \mathrm{RF}, \mathrm{SO}_{4}, \mathrm{Na}, \mathrm{BOD} 5$ from urban point sources is about $68 \%$ of the total (Fig.3).

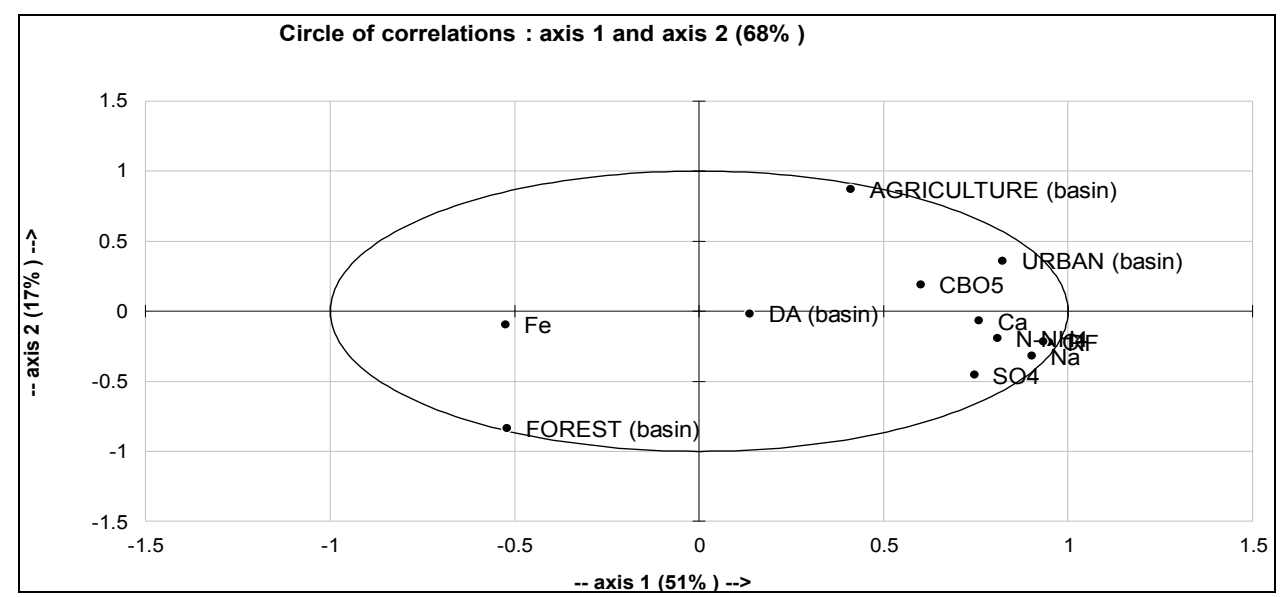

Fig.4. Correlation of non-point pollution sources of river and land use

So point sources are overwhelmingly and should be the priority for control and abatement. Non-point pollution sources should also be paid adequate attention.

The urban point pollution sources are the principal sources, the non-point pollution sources take the second place, and the internal pollution sources are less significant.

So wastewater treatment plants in cities and towns along the main route should be built as soon as possible to ensure the water quality in Water Framework Directive (WFD) (2000/60/CE). 


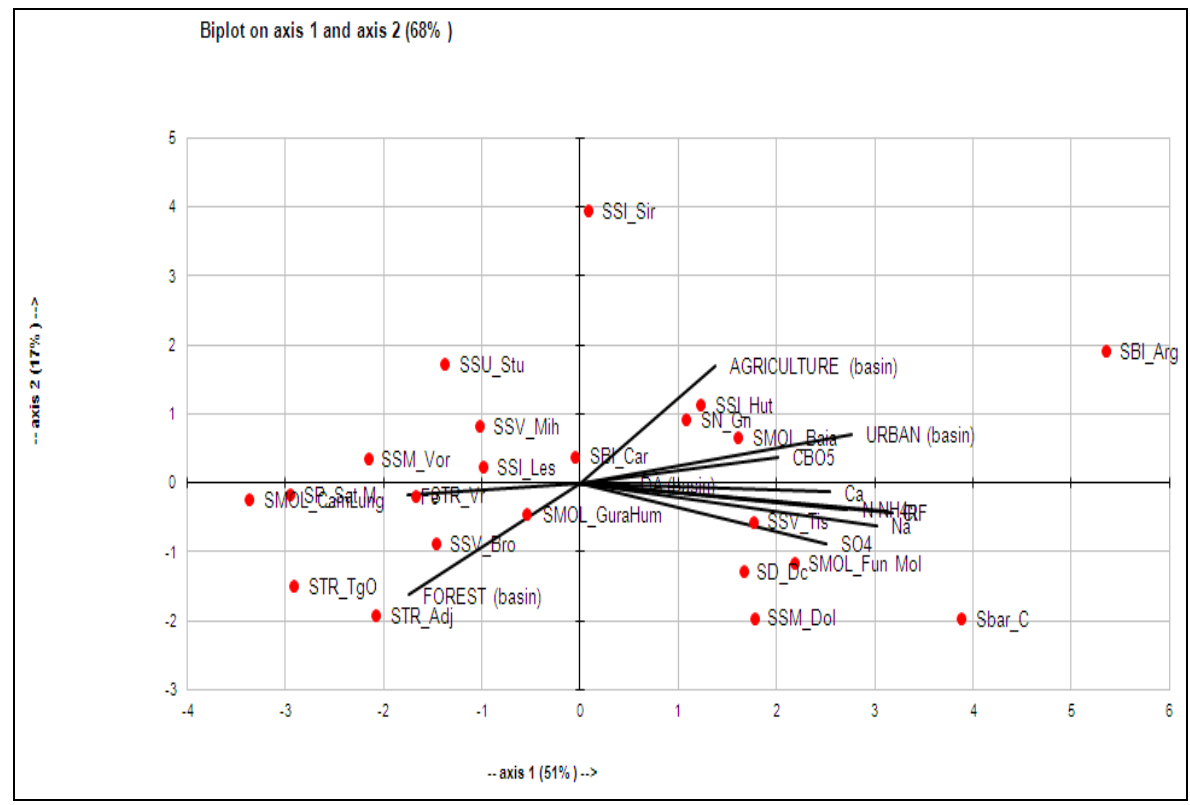

Fig.4. Correlation of non-point pollution sources of Siret River section and land use

\section{Results}

This study is concerned with ambient water quality in Siret River Basin. For the analysis data on water quality for 22 monitoring points on 6 important rivers for six years 2006-2011 are used. These data collected under the water quality monitoring program of the government have been taken from the web site of the Siret Regional Water (www.apesiret.uvp.ro.). Most of the selected sites matched with the Water Framework Directive criterion of being free from human influence. Inasmuch as the discharge of urban wastewater is an important cause of pollution of Siret Rivers, one should expect a negative relationship between urbanization and river water quality. The preliminary results of the model, however, did not show such a relationship (Fig.3) and (Table 4). A closer examination of the data suggested a relationship between urbanization and water quality. The water quality deteriorates as urbanization goes up, but beyond a stage further increases in the level of urbanization tend to be beneficial (Bishwanath G. and Nandini B., 2004). The best results that could be obtained in respect of the urbanization variable are shown as model estimate in Table 3.

The coefficient of urbanization has a negative coefficient while the agriculture, forestal of this variable has a positive coefficient. Both coefficients are statistically significant. An increase in urbanization causes deterioration in river 
water quality. However, the results do hint at an adverse effect of urbanization on river water quality up to a stage.

Tab. - 3 Correlation and PCA analysis with coefficient type Sperman's

\begin{tabular}{|c|c|c|c|c|c|c|c|c|c|c|c|c|}
\hline $\begin{array}{l}\text { SIRET RIVER } \\
\text { (basin) }\end{array}$ & $\begin{array}{c}\text { URBAN } \\
\text { (basin) }\end{array}$ & $\begin{array}{l}\text { AGRICULTURE } \\
\text { (basin) }\end{array}$ & $\underset{\text { (basin) }}{\text { EFOREST }}$ & DA (basin) & N-NH4 & $\mathrm{RF}$ & BOD5 & $\mathrm{Cl}$ & $\mathrm{SO} 4$ & $\mathrm{Ca}$ & $\mathrm{Na}$ & $\mathbf{F e}$ \\
\hline URBAN (basin) & 1 & 0.5720 & -0.7064 & 0.2772 & 0.5042 & 0.6601 & 0.5483 & 0.7391 & 0.4433 & 0.5404 & 0.6228 & -0.4458 \\
\hline $\begin{array}{l}\text { AGRICULTURE } \\
\text { (basin) }\end{array}$ & 0.5720 & 1 & -0.9774 & -0.0435 & 0.2084 & 0.2174 & 0.3123 & 0.1925 & -0.0220 & 0.2445 & 0.1078 & -0.2532 \\
\hline FOREST (basin) & -0.7064 & -0.9774 & 1 & -0.0073 & -0.2874 & -0.3145 & -0.3992 & -0.3123 & -0.0627 & -0.3055 & -0.2151 & 0.3001 \\
\hline DA (basin) & 0.2772 & -0.0435 & -0.0073 & 1 & -0.1225 & 0.0198 & -0.0864 & 0.1372 & 0.1350 & 0.1316 & 0.0898 & -0.4142 \\
\hline $\mathrm{N}-\mathrm{NH} 4$ & 0.5042 & 0.2084 & -0.2874 & -0.1225 & 1 & 0.8622 & 0.5020 & 0.7267 & 0.6307 & 0.5720 & 0.7945 & -0.2024 \\
\hline $\mathrm{RF}$ & 0.6601 & 0.2174 & -0.3145 & 0.0198 & 0.8622 & 1 & 0.5031 & 0.9334 & 0.7628 & 0.7357 & 0.9413 & -0.4554 \\
\hline BOD5 & 0.5483 & 0.3123 & -0.3992 & -0.0864 & 0.5020 & 0.5031 & 1 & 0.5234 & 0.2332 & 0.3529 & 0.4975 & -0.1160 \\
\hline $\mathrm{Cl}$ & 0.7391 & 0.1925 & -0.3123 & 0.1372 & 0.7267 & 0.9334 & 0.5234 & 1 & 0.8114 & 0.6556 & 0.9300 & -0.3961 \\
\hline $\mathrm{SO} 4$ & 0.4433 & -0.0220 & -0.0627 & 0.1350 & 0.6307 & 0.7628 & 0.2332 & 0.8114 & 1 & 0.5155 & 0.7956 & -0.3701 \\
\hline $\mathrm{Ca}$ & 0.5404 & 0.2445 & -0.3055 & 0.1316 & 0.5720 & 0.7357 & 0.3529 & 0.6556 & 0.5155 & 1 & 0.6160 & -0.4876 \\
\hline $\mathrm{Na}$ & 0.6228 & 0.1078 & -0.2151 & 0.0898 & 0.7945 & 0.9413 & 0.4975 & 0.9300 & 0.7956 & 0.6160 & 1 & -0.3656 \\
\hline $\mathbf{F e}$ & -0.4458 & -0.2532 & 0.3001 & -0.4142 & -0.2024 & -0.4554 & -0.1160 & -0.3961 & -0.3701 & -0.4876 & -0.3656 & 1 \\
\hline
\end{tabular}

The highest pollution input was recorded in the Siret River coming from the four tributaries (Trotuş, Bistrita, Moldova, Somuzu Mare) due at least partly to the collection of urban, industrial wastes and salinity. Mean value of $\mathrm{Ca}, \mathrm{N}-\mathrm{NH}_{4}, \mathrm{RF}$, $\mathrm{SO}_{4}, \mathrm{Na}$ and BOD5, were higher in large rivers because of the high percentage of both urban use. Because the water of the rivers is vulnerable to pollution sources (the collection of domestic and industrial wastewater of city) in the drainage basin of the River Trotuş were delineated four "zones of protection" related over the surface. In the drainage basin of the River Trotuş importance are mineral waters. Critical areas that require improvement in the quality of the water in terms of ecological status. Disturbing sources are presented based on the critical areas of the basin in which it appeared that the impact of the degradation of water quality. Due to the fact that industrial objectives were developed in urban centers, municipal sewage may comprise of a mixture of household waste, waste water, industrial and waste water from various activities, including public water from precipitation and, in the area of the river basin was used notably Trotus channeling in the system unit.

Thus, on the variation of concentrations of chlorides can affirm that they grow significantly from upstream to downstream, source of chlorides being Tg.Ocna area, where natural resources are occupied by salt, taking place in Vrânceni comparative strengths with the Tg.Ocna, but which fall within the category III water quality of (WFD) the Trotuş River. 
The main source of pollution of the Şomuzu Mare River is due mainly to disposal of wastewater and usually directed by inappropriate treatment. Based on the monitoring indicators agreed levels, grade falls into water courses. For knowing the quality of water flowing in the Siret River basin during the year 2010 have collected from river water samples Şomuzu Mare Vorniceni and Dolheşti city. The main sources of pollution in the catchment area have influenced the state of its river water quality. After analyzing the variation in quality indicators increased physical - chemical river water quality Şomuzu Mare Dolheşti monitoring section in 2010, decreased due to nitrite indicator, inducing a weak class quality Şomuzu Mare River, falling in the fourth grade of quality. The main sources of river pollution in Moldova can be ranked according to: the impact on the pollutant toxicity evacuated in receiver, potential or actual danger they pose to downstream users, the amount limits set for evacuated contaminants.

Tab. - 4 Analysis some parameters of relatively unpolluted with coefficient type Spearman's

\begin{tabular}{|c|c|c|c|c|c|c|c|c|c|c|c|c|}
\hline $\begin{array}{l}\text { SIRET RIVER } \\
\text { (basin) }\end{array}$ & factor 1 & factor 2 & factor 3 & factor 4 & factor 5 & factor 6 & factor 7 & factor 8 & factor 9 & $\begin{array}{c}\text { factor } \\
10\end{array}$ & $\begin{array}{c}\text { factor } \\
11\end{array}$ & $\begin{array}{c}\text { factor } \\
12\end{array}$ \\
\hline $\begin{array}{l}\text { URBAN (basin) } \\
\text { AGRICULTURE }\end{array}$ & 0.8224 & 0.3601 & 0.1364 & 0.2167 & -0.1174 & 0.0422 & -0.1485 & -0.2167 & 0.2041 & 0.0430 & 0.0140 & 0.0129 \\
\hline (basin) & 0.4110 & 0.8695 & -0.0670 & -0.1684 & -0.1289 & 0.0154 & 0.0424 & 0.1071 & -0.0980 & -0.0121 & 0.0161 & 0.0454 \\
\hline FOREST (basin) & -0.5202 & -0.8348 & 0.0471 & 0.0817 & 0.1350 & -0.0079 & -0.0110 & -0.0401 & 0.0151 & -0.0086 & 0.0206 & 0.0542 \\
\hline DA (basin) & 0.1377 & -0.0168 & 0.8623 & 0.3904 & -0.1112 & 0.1880 & 0.1665 & 0.0824 & -0.0492 & -0.0138 & 0.0058 & -0.0024 \\
\hline $\mathrm{N}-\mathrm{NH} 4$ & 0.8085 & -0.1946 & -0.3354 & -0.0744 & -0.0296 & 0.0863 & 0.4059 & 0.0046 & 0.1286 & -0.0122 & -0.0251 & 0.0067 \\
\hline RF & 0.9495 & -0.2226 & -0.0936 & -0.0981 & 0.0181 & -0.0032 & 0.0613 & -0.1017 & -0.0756 & -0.0628 & 0.0784 & -0.0173 \\
\hline BOD5 & 0.6022 & 0.1891 & -0.3643 & 0.5335 & 0.3710 & -0.1542 & -0.0157 & 0.1503 & -0.0038 & -0.0004 & 0.0055 & 0.0000 \\
\hline $\mathrm{Cl}$ & 0.9341 & -0.2153 & -0.0154 & 0.0898 & -0.1254 & -0.0207 & -0.1566 & -0.0739 & -0.0768 & -0.1347 & -0.0504 & 0.0074 \\
\hline SO4 & 0.7466 & -0.4537 & 0.0746 & -0.1140 & -0.2922 & -0.1272 & -0.1379 & 0.2947 & 0.1000 & 0.0230 & 0.0128 & -0.0019 \\
\hline $\mathrm{Ca}$ & 0.7587 & -0.0690 & 0.1267 & -0.2560 & 0.3812 & 0.4087 & -0.1396 & 0.0751 & 0.0083 & 0.0213 & -0.0084 & 0.0004 \\
\hline $\mathrm{Na}$ & 0.9014 & -0.3194 & -0.0776 & 0.0566 & -0.1000 & -0.0473 & 0.0206 & -0.0919 & -0.1851 & 0.1432 & -0.0170 & 0.0032 \\
\hline $\mathrm{Fe}$ & -0.5239 & -0.0948 & -0.6356 & 0.2744 & -0.2952 & 0.3780 & -0.0682 & 0.0399 & -0.0282 & -0.0003 & 0.0124 & -0.0029 \\
\hline
\end{tabular}

The main source of pollution of the Bistriţa River are mining and urban, they raised a number of pressing issues affecting the environmental factors. Water pollution is reduced substantially from its initial value due to its self-purification capacity. Treated or untreated wastewater, after evacuation processes are subjected to physical, chemical and biological processes leading to water self-purification of receptor. This is because in some areas affected by pollution from mines, streams have low flow rates.

Water pollution is achieved in several ways: mine drainage water (slightly acidic water), discharge to surface waters, pollution of surface material from waste dumps, water washing by precipitation, infiltration of the operation in underground 
aquifers, loss of fuel or lubricants from equipment equipped with internal combustion engines, sawdust resulting from cutting the material used to reinforce galleries. After monitoring the river water quality was determined concentration Bistriţa $\mathrm{Ca}, \mathrm{N}-\mathrm{NH}_{4}, \mathrm{RF}, \mathrm{SO}_{4}, \mathrm{Na}, \mathrm{BOD} 5, \mathrm{Cl}$ and $\mathrm{Fe}$ in the control section Bărnar, Bărnărel - Crucea, Argeşu and Cârlibaba. In terms of ion content in setting state water quality leads to the Siret River water quality classification as "moderate"class.

Tab. - 5 Analysis some parameters of relatively unpolluted with coefficient type Spearman's

\begin{tabular}{|c|c|c|c|c|c|c|c|c|c|c|c|c|}
\hline $\begin{array}{l}\text { SIRET RIVER } \\
\text { (basin) }\end{array}$ & 1 & 2 & 3 & 4 & 5 & 6 & 7 & 8 & 9 & 10 & 11 & 12 \\
\hline Value & 6.1452 & 2.0741 & 1.4547 & 0.6992 & 0.5434 & 0.3974 & 0.2886 & 0.2078 & 0.1272 & 0.0460 & 0.0109 & 0.0056 \\
\hline$\%$ of variability. & 0.5121 & 0.1728 & 0.1212 & 0.0583 & 0.0453 & 0.0331 & 0.0240 & 0.0173 & 0.0106 & 0.0038 & 0.0009 & 0.0005 \\
\hline Cumulated \% & 0.5121 & 0.6849 & 0.8062 & 0.8644 & 0.9097 & 0.9428 & 0.9669 & 0.9842 & 0.9948 & 0.9986 & 0.9995 & 1.0000 \\
\hline Vectors : & 1 & 2 & 3 & 4 & 5 & 6 & 7 & 8 & 9 & 10 & 11 & 12 \\
\hline URBAN (basin) & 0.3318 & 0.2500 & 0.1131 & 0.2591 & -0.1593 & 0.0669 & -0.2765 & -0.4753 & 0.5722 & 0.2007 & 0.1338 & 0.1721 \\
\hline $\begin{array}{l}\text { AGRICULTURE } \\
\text { (basin) }\end{array}$ & 0.1658 & 0.6038 & -0.0556 & -0.2014 & -0.1748 & 0.0244 & 0.0790 & 0.2350 & -0.2748 & -0.0566 & 0.1536 & 0.6078 \\
\hline FOREST (basin) & -0.2098 & -0.5796 & 0.0391 & 0.0977 & 0.1831 & -0.0126 & -0.0205 & -0.0880 & 0.0423 & -0.0401 & 0.1972 & 0.7244 \\
\hline DA (basin) & 0.0555 & -0.0117 & 0.7149 & 0.4669 & -0.1509 & 0.2982 & 0.3100 & 0.1807 & -0.1378 & -0.0645 & 0.0559 & -0.0315 \\
\hline N-NH4 & 0.3261 & -0.1351 & -0.2781 & -0.0890 & -0.0402 & 0.1369 & 0.7556 & 0.0101 & 0.3607 & -0.0570 & -0.2396 & 0.0895 \\
\hline RF & 0.3830 & -0.1546 & -0.0776 & -0.1174 & 0.0246 & -0.0050 & 0.1142 & -0.2230 & -0.2120 & -0.2927 & 0.7499 & -0.2308 \\
\hline BDO5 & 0.2429 & 0.1313 & -0.3020 & 0.6380 & 0.5033 & -0.2446 & -0.0293 & 0.3297 & -0.0105 & -0.0018 & 0.0523 & -0.0002 \\
\hline $\begin{array}{c}\mathrm{Cl} \\
\mathrm{SO} 4\end{array}$ & $\begin{array}{l}0.3768 \\
0.3012\end{array}$ & $\begin{array}{l}-0.1495 \\
-0.3151\end{array}$ & $\begin{array}{c}-0.0128 \\
0.0618\end{array}$ & $\begin{array}{r}0.1074 \\
-0.1363\end{array}$ & $\begin{array}{l}-0.1701 \\
-0.3964\end{array}$ & $\begin{array}{l}-0.0329 \\
-0.2017\end{array}$ & $\begin{array}{l}-0.2915 \\
-0.2567\end{array}$ & $\begin{array}{r}-0.1621 \\
0.6466\end{array}$ & $\begin{array}{l}-0.2152 \\
0.2803\end{array}$ & $\begin{array}{l}-0.6280 \\
0.1072\end{array}$ & $\begin{array}{l}-0.4818 \\
0.1226\end{array}$ & $\begin{array}{r}0.0991 \\
-0.0256\end{array}$ \\
\hline $\mathrm{Ca}$ & 0.3060 & -0.0479 & 0.1051 & -0.3061 & 0.5172 & 0.6483 & -0.2599 & 0.1647 & 0.0232 & 0.0992 & -0.0804 & 0.0052 \\
\hline $\begin{array}{l}\mathrm{Na} \\
\mathrm{Fe}\end{array}$ & 0.3636 & -0.2218 & -0.0643 & 0.0677 & -0.1357 & -0.0750 & 0.0384 & -0.2017 & -0.5191 & 0.6679 & -0.1622 & 0.0432 \\
\hline $\mathrm{Fe}$ & -0.2113 & -0.0658 & -0.5270 & 0.3282 & -0.4004 & 0.5996 & -0.1270 & 0.0875 & -0.0791 & -0.0012 & 0.1189 & -0.0389 \\
\hline
\end{tabular}

\section{Discussion}

According to the WFD the assessment of the physical-chemical status of water bodies should be performed using physical-chemical indicators. This has generated a debate among the scientific community regarding the use indicators group and land use to evaluate quality water. Industrial production without adequate regard for environmental impacts has increased water and air pollution, and has led to soil degradation and large-scale global impacts such as acid rain, global warming, and ozone depletion (Seth S.M., 2003). Many studies have discussed which physical-chemical elements are apporiate for defining (Wang C.et. al, 2005; Shuguang L.et al, 2011; Y.C. Lai et.al., 2011; Jinzhu M. et.al., 2009; Akkoyunlu A and Muhammed E.A., 2012).

In the present study we used physical-chemical elements to study the impact of quality water Siret River Basin. 
According to the European Environmental Agency, in many catchments the main source of $\mathrm{N}_{-} \mathrm{NH}_{4}, \mathrm{Ca}, \mathrm{RF}, \mathrm{SO}_{4}, \mathrm{Na}, \mathrm{BOD} 5, \mathrm{Cl}$ and Fe pollution is form urban land and discharges from wastewater treatment (EEA, 2003). The relationship between land uses and $\mathrm{N}-\mathrm{NH}_{4}(>0,3 \mathrm{mg} / \mathrm{l}), \mathrm{RF}(>500 \mathrm{mg} / \mathrm{l}), \mathrm{SO}_{4}(>150 \mathrm{mg} / \mathrm{l})$, $\mathrm{Na}(>50 \mathrm{mg} / \mathrm{l}), \mathrm{BOD} 5\left(>5 \mathrm{mg} / \mathrm{OO}_{2}\right), \mathrm{Cl}(>100 \mathrm{mg} / \mathrm{l})$ and $\mathrm{Fe}(>0,3 \mathrm{mg} / \mathrm{l})$ and $\mathrm{Ca}(>300$ $\mathrm{mg} / \mathrm{l})$ concentration in this study produced important conclusions. Urban use increased showed negative correlation correlations whit $\mathrm{N}-\mathrm{NH}_{4}, \mathrm{RF}, \mathrm{SO}_{4}, \mathrm{Na}$ and Cl. Ammonium, BOD5 and ammonia was correlated whit urban use, thus indicating high industrial and population densities.

The urban sewage also produces serious pollution in some rivers studied, for example in the Siret River Basin, which receives high urban and industrial inputs of pollution from the Trotuş River. The pollution effect in the Siret River Basin has been amplified due to upstream water and other interbasin (for example Suceava River, Bistrita River, Somuzu Mare River, Moldova River). Between 1993 - 2003 there were 184 pollution incidents, with a minimum of 10 pollution in 1996 and a maximum of 28 in 2001. of the total pollution accidents occurring in this period $46.2 \%$ were recorded Trotuş River and its tributaries, $26.1 \%$ were recorded on Bistriţa River and its tributaries, and 9.8\% were registered on the Siret River. The central objective of the Water Framework Directive (Directive 2000/60/EC) is to achieve "good status" for all water bodies, both the surface and those of groundwater, except bodies and heavily modified artificial, which defines "good ecological potential."

\section{Conclusions}

The paper investigated determinants of water quality in rivers in Romania, particularly the effectiveness of informal regulation in controlling pollution of rivers. Data on water quality (water class) for 22 monitoring points for six years $(2006-2011)$ were used for the analysis. Given the nature of the water quality data, an ordinary regression analysis could not be applied. The statistical analysis was therefore carried out by using a StatSoft v.10 program. The results indicated a positive relationship between land use and water quality in rivers. A significant negative relationship was found between the levels of industrialization and urban the water quality in the monitoring point falling in the district. A significant positive relationship was found between agricultural, forest percentage and water quality. The results also indicated a positive relationship between the water quality in rivers flowing through and mining. These results may be taken as indicative of a significant favorable effect of WFD water quality rivers in Siret River Basin. 
Acknowledgments. This paper was realized with the support of POSDRU CUANTUMDOC "DOCTORAL STUDIES FOR EUROPEAN PERFORMANCES IN RESEARCH AND INOVATION" ID79407 project funded by the European Social Found and Romanian Government.

\section{References:}

Alexander, R.B., Smith, R.A., Schwarz, G.E.,( 2000). Effect of stream channel size on the delivery of nitrogen to the Gulf of Mexico. Nature 403 (6771), 758-761.

Basnyat, P., Teeter L.D., Lockaby, B.G., Flynn, K.M., (2000). The use of remote sensing and GIS in watershed level analses of non point source pollution. Forest Ecology and Management, 128, 67-73.

Behrendt, H., Bachor, A., (1998). Point and diffuse load of nutrients to the Baltic Sea by river basins of North East Germany (Mecklenburg-Vorpommern). Water Sci.Technol. 38 (10), 147-155.

EEA, (2003). Europe's water: An indicator-based assessment, topic report No1/2003. European Evnironvent Agency, Copenhagen.

Lammert, M., Allan, J.D., (1999). Assessing biotic integrity of streams: effects of scale in measuring the influence of land use/cover and habitar structure in fish and macroinvertebrates. Environ. Manage. 23, 257-270.

Luca, M., (2004). Considerations on the phenomenon of pollution induced by mining dumps. International coference "Polluation and Disaster Monitoring", Science, Performantica, Gh Asachi Tehnical University, ISBN 978-973-730-406-3.

McDonnell, R.A., (2000). Hieratchical modeling of the environmental impacts of river impoundment based on a GIS. Hydrological Processes, 14, 2123-2142.

Monteagudo, L., Moreno, J.L., Picazo, F., (2012). River eutrophication: Irrigated vs. Non-irrugated agriculture through different spatial scales. Water Research XXX, 113.

Moreno, J.L., Navarro, C., De las Heras, J., (2006). Abiotic ecotypes in Routh-central Spanish rivers: Reference conditions and pollution. Enivironmental Pollution 143, 388-396.

Richards, C., Host, G., (1994). Examining land use influence on stream habitats and macroinveterbrates: a GIS approach. Journal of American Water Resources Association 30, 729-738

Shuguang, L., Sha, L., Cuiping, K., Wenrui, H., Wujun, C., Jianle, Z., Guihui, Z., (2011), Water quality assessment by pollution-index method in the coastal waters of Hebei Province in western Bohai Sea, China, Marine Pollution Bulletin 62, 22202229.

Simeonov, V., Stratis, J.A., Samara, C., Zachariadis, G., Voutsa, D., Anthemidis, A., Sofoniou, M., Kouimtzis, T., (2003). Assessment of the surface water quality in Northern Greece. Water Research 37 (17), 4119-4124.

Singh, K.P., Malik, A., Sinha, S., (2005). Water quality assessment and apportionment of pollution sources of Gomti river (India) using multivariate statistical techniquesea case study. Analytica Chimica Acta 538, 355-374. 
Wang, C., Wang, Yan-Ying, Wang, Pei-Fang, (2006). Water quality modeling and pollution control for the eastern route of south to north water transfer project in China. Journal of Hydrodynamics, 18, 253-261.

WATECO (Working Group WATer Framework Directive Economics), (2003). Policy Summary to Guidance Document No 1: Economics and the Environment - The Implementation Challenge of the Water Framework Directive. Common implementation strategy for the Water Framework Directive (2000/60/EC).

http://www.apesiret.uvp.ro.

$\underline{\text { http://data.freshwaterbiodiversity.eu/shapefiles.html }}$

http://hydrosheds.cr.usgs.gov. 